\title{
Soil quality and soybean productivity in crop-livestock integrated system in no-tillage
}

\author{
Jackeline Vieira dos Santos Laroca(1), Juliana Mendes Andrade de Souza(1), Gabriela Castro Pires ${ }^{(1)}$, \\ Gleidson José Coutinho Pires ${ }^{(1)}$, Leandro Pereira Pacheco(1), Francine Damian da Silva ${ }^{(1)}$, \\ Flávio Jesus Wruck ${ }^{(2)}$, Marco Aurélio Carbone Carneiro ${ }^{(3)}$, Laércio Santos Silva(4) \\ and Edicarlos Damacena de Souza ${ }^{(1)}$
}

\begin{abstract}
(1)Universidade Federal de Mato Grosso, Campus Universitário de Rondonópolis, Rodovia Rondonópolis-Guiratinga, Km 06 (MT270), Sagrada Família, CEP 78735-000 Rondonópolis, MT, Brazil. E-mail: jacke.laroca@gmail.com, juhh.mendes@hotmail.com, gabrielacpires@hotmail.com, gleidson_coutinho@outlook.com, leandroppacheco@gmail.com, frandamian@hotmail.com, edidamacena2000@yahoo.com.br (2)Embrapa Agrossilvipastoril, Rodovia MT-222, Km 2,5, CEP 78550-970 Sinop, MT, Brazil. E-mail: flavio.wruck@embrapa.br ${ }^{(3)}$ Universidade Federal de Lavras, Departamento de Ciência do Solo, Caixa Postal 3.037, CEP 37200-000 Lavras, MG, Brazil. E-mail: marcocarbone@dcs.ufla.br (4)Universidade Estadual Paulista, Via de Acesso Prof. Paulo Donato Castellane, Km 5, s/no , Vila Industrial, CEP 14890-675 Jaboticabal, SP, Brazil. E-mail: laerciosantos18@gmail.com
\end{abstract}

\begin{abstract}
The objective of this work was to evaluate the quality of the soil and its relation with soybean (Glycine max) yield in an integrated crop-livestock system (ICLS), with intercropping between grasses and legumes in the pasture phase. The experiment was carried out in the state of Mato Grosso, Brazil, on a dystrophic Oxisol, in which grasses (Megathyrsus maximus 'BRS Tamani' and Urochloa brizantha 'BRS Piatã'), intercropped with cowpea (Vigna unguiculata 'BRS Tumucumaque') and pigeon pea (Cajanus cajan 'BRS Mandarim'), were cultivated after soybean harvest. A randomized complete block design was used, with three replicates, in a split-plot arrangement, in which grasses were considered as plots, and legumes as subplots. Legume intercrops provided increases of $\mathrm{C}$ and total $\mathrm{N}$ stocks. The intercrops caused the increase of $\mathrm{C}$ and $\mathrm{N}$ of the microbial biomass, whereas the single cultures contributed to stress in the soil microbiota. The activity of the urease enzyme was sensitive to management changes in the short term, but acid phosphatase and $\beta$-glucosidase were poorly sensitive indicators. Soil quality is high with intercropping between grasses and legumes, with positive effects on soybean grain yield.
\end{abstract}

Index terms: Cerrado, cowpea, microbial biomass, pigeon pea, soil organic matter.

\section{Qualidade do solo e produtividade de soja em sistema de integração lavoura-pecuária em plantio direto}

Resumo - O objetivo deste trabalho foi avaliar a qualidade do solo e sua relação com a produtividade de soja (Glycine max) em sistema de integração lavoura-pecuária (ILP), com consórcio entre gramíneas e leguminosas na fase pastagem. O experimento foi realizado no Estado de Mato Grosso, em um Latossolo Vermelho distrófico, em que gramíneas (Megathyrsus maximus 'BRS Tamani' e Urochloa brizantha 'BRS Piatã'), consorciadas com feijão-caupi (Vigna unguiculata 'BRS Tumucumaque') e feijão-guandu (Cajanus cajan 'BRS Mandarim'), foram cultivadas após a colheita da soja. Um delineamento experimental de blocos ao acaso foi utilizado com três repetições, em arranjo de parcelas subdivididas, em que as gramíneas foram consideradas como parcelas, e as leguminosas, como subparcelas. Os consórcios com leguminosas proporcionaram incrementos dos estoques de $\mathrm{C}$ e $\mathrm{N}$ total. Os consórcios causaram o aumento de $\mathrm{C}$ e $\mathrm{N}$ da biomassa microbiana, enquanto os cultivos solteiros contribuíram para o estresse da microbiota do solo. A atividade da enzima urease foi sensível às alterações de manejo em curto prazo, porém a fosfatase ácida e a $\beta$-glucosidase foram indicadores pouco sensíveis. A qualidade do solo é elevada com os consórcios entre gramíneas e leguminosas, com efeitos positivos sobre a produtividade de grãos de soja.

Termos para indexação: Cerrado, feijão-caupi, biomassa microbiana, feijão-guandu, matéria orgânica do solo.

\section{Introduction}

The major challenge faced by agriculture nowadays is to meet the demands of a highly productive potential, with a reduction of the agricultural expansion, together with the environmental quality and financial returns to producers (Roesch-McNally et al., 2018). These aims can be achieved through the use of technologies 
such as the integrated crop-livestock systems (ICLS) and the no-tillage system (NTS). These systems are characterized by the development of animal and plant production in a concomitant or sequential way, in order to enable the best use of soil and other environmental resources, as well as to provide economic benefits (Carvalho et al., 2016).

The use of ICLS-NTS contributes to higher stocks of soil organic matter, improving plant nutrition through nutrient cycling, particularly by recoupling $\mathrm{N}$ and $\mathrm{C}$ cycles, and favoring the flow and storage of water, thus raising the quality of soil (Ryschawy et al., 2017). In addition, it contributes to the reduction of costs due to the smaller input of supplies and diversification in the agricultural and livestock sector, allowing of the income increase and impact reduction to the environment, aiming at sustainability.

The association ICLS-NTS helps the increase of C due to the high-plant development both in the shoots and roots combined with animal grazing, which acts as a system catalyzer (Franzluebbers \& Stuedemann, 2009). In this regard, Gazolla et al. (2015), in a study in the Cerrado area, observed $\mathrm{C}$ content increases around $25.72 \mathrm{~g} \mathrm{~kg}^{-1}$ in ICLS-NTS, in comparison to Urochloa decumbens pasture. Alves et al. (2011), when evaluating microbial attributes which are highly sensitive indicators of changes in soil management, observed 55\% increases in the microbial biomass $\mathrm{C}$ in areas of ICLS, in comparison to tillage, and $60 \%$ in comparison to the native area of Cerrado.

Therefore, it is necessary to evaluate soil quality through multiple indicators. In this context, soil organic matter is the key point to increase soil quality because it is connected to the increase of soil microbial biomass and, consequently, to soil respiration, which are indicated as excellent short-term indicators of anthropogenic interventions, and can be used to compare soil quality under different managements (Costa et al., 2015). Enzymes are also being widely used as they allow of the measuring of the catabolism of organic and mineral components in the soil, and also because they are highly sensitive to provide information about changes in key soil functions (Lisboa et al., 2012).

However, there is a need to increase the use and efficiency of ICLS-NTS for a better use of soil, nutrients, and the environment, as benefits such as the maintenance of soil quality, can be enhanced by the insertion of intercropping of grasses with legumes in the pasture phase. It is expected that increasing species diversity will lead to greater soil covering, better incorporation of plant material into the soil, higher availability of $\mathrm{N}$ due to biological fixation, and greater microbial and enzymatic activity of the soil. As a consequence of the soil quality improvement, it is expected that these systems would boost grain yield because of the greater plant diversity.

The objective of this work was to evaluate the soil quality and its relation with soybean yield in ICLSNTS, with intercropping between grasses and legumes in the pasture phase.

\section{Materials and Methods}

The experiment was carried out in 2014, in the Fazenda Gravataí $\left(54^{\circ} 51^{\prime} 16^{\prime \prime} \mathrm{W}, 17^{\circ} 9^{\prime} 37^{\prime \prime} \mathrm{S}\right)$, in the municipality of Itiquira, in the state of Mato Grosso, Brazil. The climate of the region is classified as type Aw, according to the Köppen-Geiger's classification, with rainy periods between October and April and dry ones between May and September. The distribution of rainfall and average temperatures in the experimental area, from 2015 to 2017, was monitored (Figure 1).

The soil is classified as a Latossolo Vermelho distrófico (Santos et al., 2013), i.e., a dystrophic Oxisol, with a clayey texture. Soil samples were collected at $0-0.20-\mathrm{m}$ depth, before the establishment of the experiment in 2014, in order to determine the chemical and physical properties of the experimental area: $5.3 \mathrm{pH}\left(\mathrm{H}_{2} \mathrm{O}\right) ; 28.2 \mathrm{mg} \mathrm{dm}^{-3} \mathrm{P} ; 91.0 \mathrm{mg} \mathrm{dm}^{-3} \mathrm{~K}^{+} ; 2.7$ $\mathrm{cmol}_{\mathrm{c}} \mathrm{dm}^{-3} \mathrm{Ca}^{2+} ; 0.9 \mathrm{cmol}_{\mathrm{c}} \mathrm{dm}^{-3} \mathrm{Mg}^{2+} ; 0.2 \mathrm{cmol}_{\mathrm{c}} \mathrm{dm}^{-3}$ $\mathrm{Al}^{3+} ; 8.8 \mathrm{cmol}_{\mathrm{c}} \mathrm{dm}^{-3}$ cations exchange capacity; $43.4 \%$ base saturation; and 480, 120, and $400 \mathrm{~g} \mathrm{~kg}^{-1}$ clay, silt, and sand, respectively; and $1.38 \mathrm{~kg} \mathrm{dm}^{-3}$ soil bulk density.

In the years before the implementation of the experiment, the area was cultivated under no-tillage, with soybean culture and, in some years, with winter corn. This system was carried out from 1993 to 2004. Later, the farm specialized in cotton cultivation until 2011. From the 2011/2012 crop on, soybean was grown in the crop season, and pastures of Urochloa ruziziensis were cultivated in the off-season, under no-tillage system. In 2014, this experimental protocol was established with the soybean crop, and from that time on, it was cultivated in the crop season, and the

Pesq. agropec. bras., Brasília, v.53, n.11, p.1248-1258, Nov. 2018 DOI: 10.1590/S0100-204X2018001100007 
treatments were cultivated after the soybean harvest, in the second crop.

A randomized complete block design was carried out, with three replicates, in a subdivided-plot arrangement, in which the grasses $M$. maximus 'BRS Tamani' and $U$. brizantha 'BRS Piatã' were considered as plots. Legumes represented the subplots with cowpea (V. unguiculata 'BRS Tumucumaque' and pigeon pea (C. cajan 'BRS Mandarim' cultivated in intercropping, as well as grasses cultivated alone. Each experimental plot (picket) had an approximate size of 3.5 ha; the total area of the experiment was approximately 60 ha.

The cultivar TMG 1174 RR of soybean was sown annually between October and November. The following fertilizers were applied to sowing: $50 \mathrm{~kg}$ $\mathrm{ha}^{-1}$ of monoammonium phosphate (MAP), $120 \mathrm{~kg} \mathrm{ha}^{-1}$ of potassium chloride and $290 \mathrm{~kg} \mathrm{ha}^{-1}$ of single super phosphate.

Two herbicide applications were used to control weeds, both using glyphosate. Three applications of fungicides were carried out, the first one at the $\mathrm{R}_{1}$ stage, and the other two with 21-day-interval between them. The application of insecticides was due to the occurrence of pests in the crop cycle.

The soybean harvest was carried out annually, in February, in the whole plot, with an automated harvester, to obtain the grain weight, which was then corrected to $13 \%$ moisture. In the 2015/2016 and 2016/2017 crop seasons, the crops were evaluated for the accumulated productivity of soybean grains in two years.

After soybean harvest, the sowings were performed for grass (broadcasted) and legume (sown in line), at
$0.45 \mathrm{~m}$ spacing. Viable pure seed of grass $\left(4 \mathrm{~kg} \mathrm{ha}^{-1}\right)$ and of legumes $\left(21 \mathrm{~kg} \mathrm{ha}^{-1}\right)$ were used. There was no fertilization for the pasture phase, since one of the characteristics of the experiment was the use of residual soybean crop to supply the pasture demand.

Animal entries occurred at the same time for all treatments. U. brizantha showed a more accelerated growth habit than $M$. maximus; however, this factor was not a cause of variation. The stocking rate (AU) was chosen according to dry matter availability, as follows: 2.8 $\mathrm{AU}^{-1} \mathrm{ha}^{-1}$, 'BRS Tamani' + cowpea; 2.0 AU ha $^{-1}$, 'BRS Tamani' + pigeon pea; $1.8 \mathrm{AU}^{\mathrm{ha}^{-1}}$ 'BRS Tamani' alone; 3.3 AU ha-1, 'BRS Piatã' + cowpea; 3.1 AU ha ${ }^{-1}$, 'BRS Piatã' + pigeon pea; and 2.5 AU ha $^{-1}$, 'BRS Piatã' in a single cropping. Nellore heifers weighing between 210 and $260 \mathrm{~kg}$ were used, and remained in the grazing area until August (90 days). After the animals left, the following residual biomass was obtained: 'BRS Tamani' + cowpea, 2,390 $\mathrm{kg} \mathrm{ha}^{-1}$ (222 $\mathrm{kg} \mathrm{ha}^{-1}$ of legume); 'BRS Tamani'+ pigeon pea, $2,975 \mathrm{~kg}$ (1,163 $\mathrm{kg} \mathrm{ha}^{-1}$ of legume); 'BRS Tamani' alone, 2,705 kg ha' ${ }^{-1}$; 'BRS Piatã' + cowpea, 3,615 kg ha $^{-1}$ (261 kg ha ${ }^{-1}$ of legume); , 'BRS Piatã' + pigeon pea, $3,037 \mathrm{~kg} \mathrm{ha}^{-1}$ (1,291 kg ha-1 of legume); and 'BRS Piatã' alone, $3,800 \mathrm{~kg} \mathrm{ha}^{-1}$. Subsequently, there was a period when the pasture was left at rest for later desiccation before soybean sowing.

After the soybean harvest, in 2016, that is, 30 months after the beginning of the experiment, the soil was sampled at the $0-0.10 \mathrm{~m}$ soil depth, with the aid of the Dutch trowel and spatula. Each plot was divided into five squares, from which five simple samples were

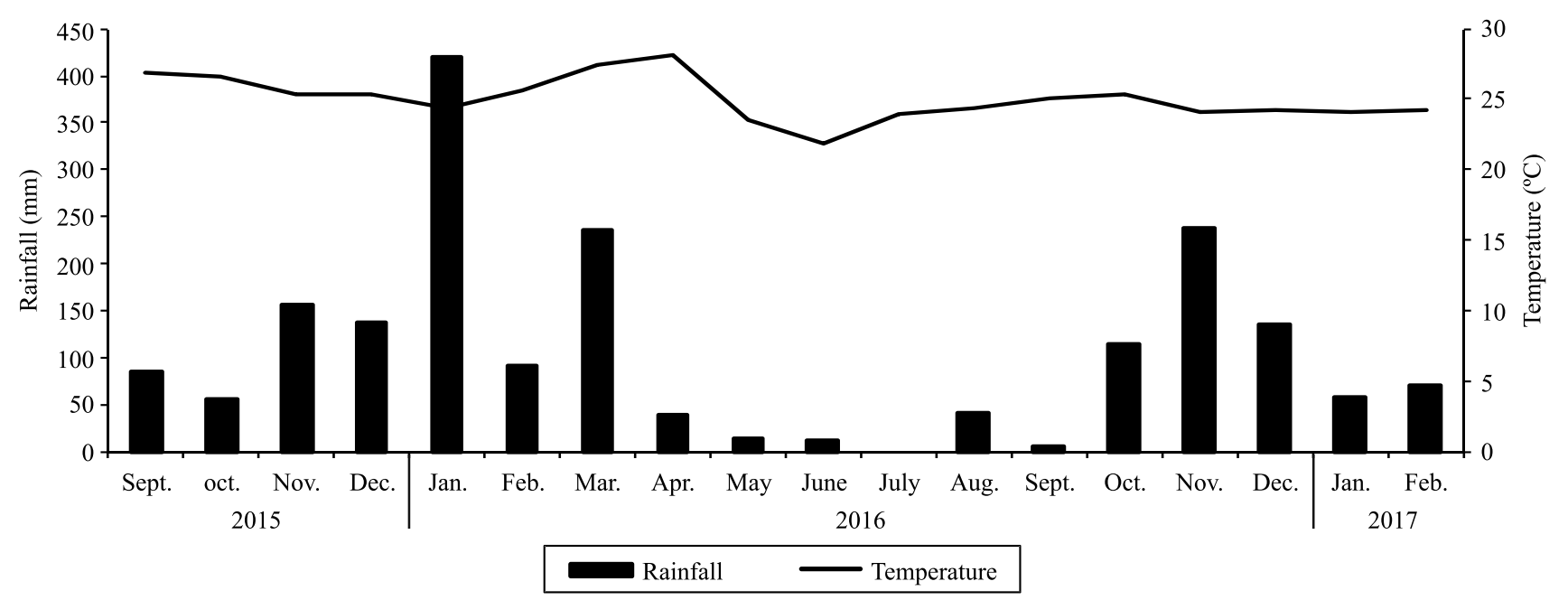

Figure 1. Distribution of rainfall and average air temperatures during the study period in the experimental area. 
collected at random points from each square, in order to form a composite sample. These five composite samples, from each experimental plot, were placed in plastic bags, and properly identified to be sent to the laboratory for microbial analyses and storage in a refrigerated place at $4^{\circ} \mathrm{C}$. The samples used to determine the chemical attributes underwent an airdrying process and, afterwards, were sieved in a $2 \mathrm{~mm}$ sieve and stored.

Total organic carbon (TOC) and total nitrogen (TN) levels were determined according to the methodology proposed by Claessen (1997). Soil stocks of COT (E-COT) and TN (E-TN) were calculated in equivalent soil masses, using the methodology of Ellert \& Bettany (1995), based on the soil density of reference, which in the present work was $1.3 \mathrm{~kg} \mathrm{dm}^{-3}$ for the 0 to $0.10 \mathrm{~m}$ soil depth.

The extraction of $\mathrm{C}$ (Vance et al., 1987) and $\mathrm{N}$ (Brookes et al., 1985) in the microbial biomass was performed by the fumigation-extraction method, with a 1:2.5 soil/extractor ratio (Tate et al., 1988), and correction factor of 0.33 and 0.54 for $\mathrm{C}$ and $\mathrm{N}$, respectively (Brookes et al., 1985; Sparling \& West, 1988). In order to determine the $\mathrm{C}$ and $\mathrm{N}$ content, the methodology proposed by Claessen (1997) was used.

Basal respiration was determined using the methodology proposed by Jenkinson \& Powlson (1976), while the metabolic quotient $\left(\mathrm{qCO}_{2}\right)$ was obtained by the ratio between the basal respiration and $\mathrm{C}$ of the microbial biomass (Anderson \& Domsh, 1993), and the microbial quotient (qMIC) was obtained by the ratio between the $\mathrm{C}$ of the microbial biomass and the COT (Sparling \& West, 1988).

The total enzymatic activity of the soil was evaluated through the hydrolysis of fluorescein diacetate (FDA) (Dick et al., 1996). The activity of urease was evaluated according to the methodology by Tabatabai \& Bremner (1972). The quantification of the $\beta$-glucosidase enzyme was evaluated according to the method by Eivazi \& Tabatabai (1988). Acid phosphatase was analyzed according to Dick et al. (1996). Finally, arylsulfatase was obtained by the method of Tabatabai (1994).

The results were subjected to the analysis of variance, and the means, when significant, were compared by the Tukey's test, at 5\% probability, using Sisvar version 5.6, from the Universidade Federal de Lavras, Brazil (Ferreira, 2011). When grasses and intercrops showed a significant interaction, the unfolding of the intercrop degrees of freedom within each grass was carried out. Moreover, the Pearson correlation analysis was performed.

After the standardization of the variables with null mean and unit variance, data were subjected to the principal component analysis (PCA), in order to itemize the soil quality indicators associated to soybean yield, and that best characterized the productive potential of each treatment in two-dimensional planes. The main components, which are the grasses (M. maximus 'BRS Tamani' and $U$. brizantha 'BRS Piatã') were generated from the eigenvalues of the covariance matrix obtained from the original variables.

Only eigenvalues higher than 1 were taken into consideration, according to the criterion proposed by Kaiser (1958). The eigenvalues and the scree-plot graph were applied to determine how many components should be excluded from the analysis; scree plot is characterized by the order of the main components, graphically representing the percentage of variance explained by each attribute. When this percentage decreases, and the curve becomes almost parallel to the abscissa axis, the corresponding components can be excluded. This analysis made it possible to qualitatively evaluate the characteristics of each intercrop for productivity, and to verify the variables most related to each one of the used intercrop. PCA was processed with the help of the Statistica 7.0 software (TIBCO Software, Palo Alto, CA, USA).

\section{Results and Discussion}

Grasses alone did not influence the accumulated productivity of soybean in the integrated crop-livestock system in no-tillage (ICLS-NTS). Additionally, the use of the intercropping promoted 416 and $338 \mathrm{~kg} \mathrm{ha}^{-1}$ increases with the use of cowpea and pigeon pea, respectively, in comparison to single cropping of grasses alone (Figure 2). Soybean cultivation subjected to the inoculation of $\mathrm{N}$-fixing bacteria does not respond to $\mathrm{N}$ fertilizer additions because it reduces the availability of oxygen, in the nodular respiration, and restricts carbohydrates to nodule metabolism (Deninson \& Harter, 1995). However, some studies have shown that $\mathrm{N}$ addition via leguminous crops may positively influence the soybean cultivation. Tanaka et al. (1992) observed increases of soybean yield, mainly

Pesq. agropec. bras., Brasília, v.53, n.11, p.1248-1258, Nov. 2018 DOI: 10.1590/S0100-204X2018001100007 
after the cultivation of leguminous plants such as crotalaria and velvet bean in the production system.

Total organic C (E-COT) and total N (E-TN) stocks showed a significant increase with the introduction of legumes in intercrop (Table 1). The intercrop with cowpea provided 33.6\% increase of E-COT, and $30.6 \%$ of E-TN, in comparison to single crop. Besides, the intercrop with pigeon pea promoted increases of $18 \%$ of E-COT and $22.4 \%$ of E-TN, in comparison to the cultivation of grasses alone. These results are related to the high input of residues deposited in these treatments, providing a greater incorporation of $\mathrm{C}$ and

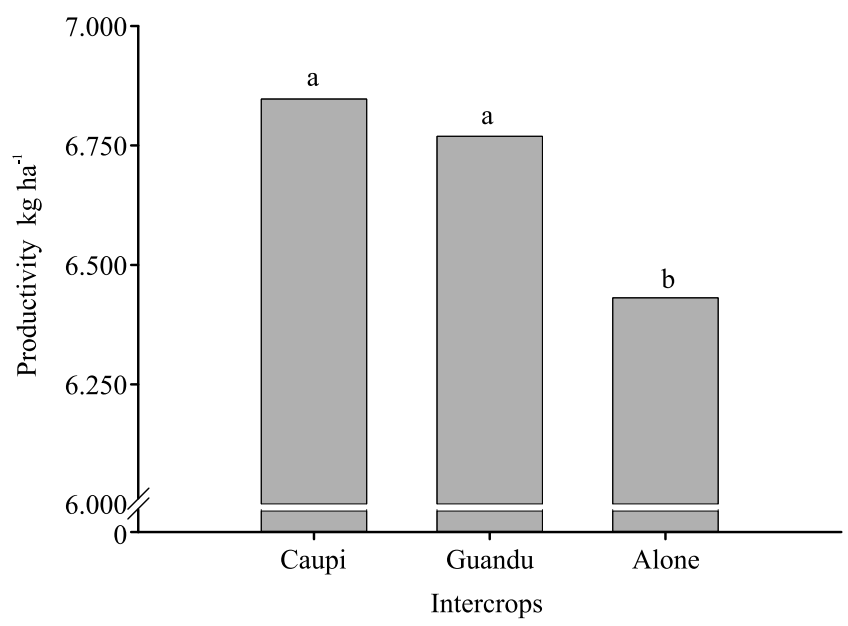

Figure 2. Accumulated productivity in two soybean cultivations, between intercrops with legumes in an integrated crop-livestock system managed in no-tillage system, in the south of Mato Grosso state, Brazil. nutrients to the soil. Similar results were found by Frasier et al. (2016), who observed increases of $\mathrm{C}$ and $\mathrm{N}$ stocks in an experiment with the use of legumes. These results reaffirm the importance of a greater soil biodiversity in order to maintain the functioning of the soil ecosystem and its services.

A ICLS-NTS with greater diversity of plants, mainly by the introduction of leguminous plants intercropped with grasses, provides a differentiated contribution of plant residues, both in quantity and quality, in comparison to the systems with grasses cultivated alone. These results directly influenced the soybean yield which showed a significant and positive correlation with E-COT $\left(\mathrm{r}=0.57^{*}\right)$ (Table 2).

Table 1. Total organic carbon stock (E-COT) and total nitrogen stock (E-TN), in an integrated crop-livestock system managed in no-tillage system with intercropping at the pasture phase ${ }^{(1)}$.

\begin{tabular}{lcc}
\hline Grass/Intercrop & E-COT & E-TN \\
& $-{ }^{2}$ & Grass \\
& $33.6^{\text {ns }}$ & $5.9^{\text {ns }}$ \\
BRS Tamani & 32.7 & 5.6 \\
BRS Piatã & & Intercrop \\
& $37.8 \mathrm{a}$ & $6.4 \mathrm{a}$ \\
Cowpea & $33.4 \mathrm{a}$ & $6.0 \mathrm{ab}$ \\
Pigeon pea & $28.3 \mathrm{~b}$ & $4.9 \mathrm{~b}$ \\
Single crop & & \\
\hline
\end{tabular}

${ }^{(1)}$ Means followed by equal letters for intercrops in the columns, do not

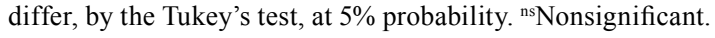

Table 2. Pearson correlation coefficients among the evaluated attributes, in an integrated crop-livestock system managed in no-tillage system with intercropping at the pasture phase.

\begin{tabular}{|c|c|c|c|c|c|c|c|c|c|c|c|}
\hline & E-COT & E-TN & C-MB & N-MB & $\mathrm{qCO}_{2}$ & qMIC & $\begin{array}{c}\beta \text {-gluco- } \\
\text { sidase }\end{array}$ & $\begin{array}{l}\text { Acid phos- } \\
\text { phatase }\end{array}$ & $\begin{array}{c}\text { Arylsul- } \\
\text { fatase }\end{array}$ & Urease & FDA \\
\hline E-TN & $0.84 *$ & & & & & & & & & & \\
\hline C-MB & $0.73 *$ & $0.50^{*}$ & & & & & & & & & \\
\hline N-MB & $0.90^{*}$ & $-0.69 *$ & $0.86^{*}$ & & & & & & & & \\
\hline $\mathrm{BR}$ & $-0.42 *$ & $-0.41 *$ & $-0.60 *$ & $-0.52 *$ & & & & & & & \\
\hline $\mathrm{qCO}_{2}$ & $-0.54 *$ & -0.43 & $-0.88^{*}$ & $-0.70 *$ & $-0.79^{*}$ & & & & & & \\
\hline$\beta$-glucosidase & -0.21 & -0.03 & -0.07 & 0.01 & -0.22 & 0.05 & & & & & \\
\hline Acid phosphatase & 0.15 & 0.26 & 0.16 & 0.20 & -0.35 & 0.10 & $0.40^{*}$ & & & & \\
\hline Arylsulfatase & 0.00 & -0.19 & 0.21 & 0.06 & -0.26 & 0.23 & -0.33 & 0.03 & & & \\
\hline Urease & 0.09 & -0.04 & $0.47 *$ & 0.21 & $-0.51^{*}$ & $0.54 *$ & -0.11 & 0.18 & $0.47 *$ & & \\
\hline FDA & -0.01 & 0.12 & -0.20 & -0.19 & 0.30 & -0.26 & -0.08 & -0.05 & $-0.68 *$ & -0.53 & \\
\hline Productivity & $0.57^{*}$ & 0.29 & $0.63 *$ & $0.55^{*}$ & -0.28 & $0.53 *$ & $-0.70 *$ & -0.05 & 0.35 & 0.38 & -0.10 \\
\hline
\end{tabular}

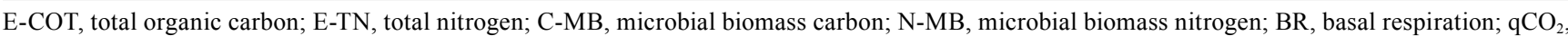
metabolic quotient; qMIC, microbial quotient; FDA, fluorescein diacetate hydrolysis. *Significant at $5 \%$ probability. 
It should be emphasized that the higher-N input to the soil-plant system, derived from the biological fixation carried out on legumes, may have contributed to improvements of soybean yield, as it is a source that is gradually released through mineralization. This result corroborates those by Cicek et al. (2014), who showed a wheat yield increase in the ICLS, with the intercropping of two species of forage legumes, and accounted this result to the $\mathrm{N}$ that was slowly added via legume residues. Moreover, cultivations of distinct species cooperate in the maintenance of nutrient balance in the soil and in the improvement of their fertility, reflecting in better yields of the successive crop.

There was a significant interaction between grasses and intercrops for $\mathrm{C}(\mathrm{C}-\mathrm{MB})$ and $\mathrm{N}$ in the microbial biomass (N-MB), as the intercrops showed higher levels of microbial $\mathrm{C}$ and $\mathrm{N}$ than the single cultures (Table 3). In the 'BRS Tamani', there were 15 and $187 \%$ increase for $\mathrm{C}-\mathrm{MB}$ and $\mathrm{N}-\mathrm{MB}$, respectively, when intercropped with cowpea in comparison to the single pasture. For 'BRS Piatã', the increment with the use of legumes was approximately 188 and $97 \%$, for $\mathrm{C}-\mathrm{MB}$ and N-MB, respectively, in comparison to the single crop. These results contributed to the increase of the microbial quotient (qMic) of 'BRS Piatã', which was $163 \%$ higher in intercrops than in single crops. In areas subjected to ICLS-NTS with intercropping using legumes, there were more favorable conditions - as temperature, humidity, and aeration - to the development of microorganisms, since they offer a greater diversity and deposition of organic residues on the soil (Alves et al., 2011). These systems also offer a greater energy supply to the soil microbial biomass by the release of exudates, such as amino acids and organic acids through the roots. Thus, the greater the presence and diversity of the roots, the greater the exudation of organic compounds that will serve as a source of $\mathrm{C}$ and energy for soil microorganisms (Chávez et al., 2011).

Increases of the $\mathrm{N}-\mathrm{MB}$ reflect a contribution of 90, 46, and $32 \mathrm{~kg} \mathrm{ha}^{-1} \mathrm{~N}$ to the soil for 'BRS Tamani' intercropped with cowpea, pigeon pea, and as a single crop, respectively. For 'BRS Piatã' grass, the contribution was 58,62 , and $30 \mathrm{~kg} \mathrm{ha}^{-1} \mathrm{~N}$ to the soil in the intercrop with cowpea, pigeon pea, and as single crop, respectively (Table 3 ). This increase of $\mathrm{N}$ inserted in the system by biological fixation directly contributes to the management of pastures with less mineral nitrogen fertilizers, since organic $\mathrm{N}$ can be transferred as a pasture fertilizer to the successive crop, significantly reducing the need for mineral fertilizers throughout the ICLS, creating a healthier soil with higher quality, and avoiding risks associated with the contamination of the environment with reactive $\mathrm{N}$ and nitrate leaching (Ryschawy et al., 2017).

It is worth highlighting that $\mathrm{C}-\mathrm{MB}\left(\mathrm{r}=0.63^{*}\right), \mathrm{N}-\mathrm{MB}$ $\left(\mathrm{r}=0.55^{*}\right)$ and $\mathrm{qMic}\left(\mathrm{r}=0.53^{*}\right)$ showed a significant correlation with soybean yield (Table 2), confirming the relevance of these attributes to the promotion of soil quality, directly resulting in higher-grain yields.

The basal respiration and metabolic quotient $\left(\mathrm{qCO}_{2}\right)$ are components related to the specific respiration of the microbial biomass, which are used as a way of measuring the metabolic activity of the soil microbial population (Silva et al., 2010). These variables showed a significant interaction between intercrops and grasses, showing high values in the single crops, and low values in the intercrops, regardless of the grass species used (Table 3). However, it is necessary to emphasize that 'BRS Piatã' grass, when intercropped with pigeon

Table 3. Microbial biomass carbon (C-MB), basal respiration $(\mathrm{BR})$, metabolic quotient $\left(\mathrm{qCO}_{2}\right)$, and microbial quotient (qMIC) of the soil, in an integrated crop-livestock system managed in no-tillage system, with intercropping at the pasture phase.

\begin{tabular}{|c|c|c|c|}
\hline \multirow{2}{*}{ Grass } & \multicolumn{3}{|c|}{ Intercrop } \\
\hline & Cowpea & Pigeon pea & Single crop \\
\hline & \multicolumn{3}{|c|}{--M-MB (mg C kg-1 soil) } \\
\hline BRS Tamani & $793.2 \mathrm{a}$ & $574.9 \mathrm{~b}$ & $369.4 \mathrm{c}$ \\
\hline \multirow[t]{2}{*}{ BRS Piatã } & $774.1 \mathrm{a}$ & $761.3 \mathrm{a}$ & $265.8 \mathrm{~b}$ \\
\hline & \multicolumn{3}{|c|}{ N-MB (mg C kg${ }^{-1}$ soil) } \\
\hline BRS Tamani & $69.8 \mathrm{a}$ & $35.5 b$ & $24.3 \mathrm{c}$ \\
\hline \multirow[t]{2}{*}{ BRS Piatã } & $44.8 \mathrm{a}$ & $47.8 \mathrm{a}$ & $23.5 b$ \\
\hline & \multicolumn{3}{|c|}{-BR (mg C-Co $\mathrm{kg}^{-1}$ soil per hour) } \\
\hline BRS Tamani & $5.7 \mathrm{~b}$ & $4.9 \mathrm{~b}$ & $9.0 \mathrm{a}$ \\
\hline \multirow[t]{2}{*}{ BRS Piatã } & $9.5 b$ & $3.5 \mathrm{c}$ & $11.2 \mathrm{a}$ \\
\hline & \multicolumn{3}{|c|}{$----\mathrm{qCO}_{2}\left[\left(\mathrm{mg} \mathrm{C}-\mathrm{Co}_{2} \mathrm{Mg}^{-1} \mathrm{C}-\mathrm{MB}\right.\right.$ per hour $\left.) \times 10^{-3}\right]$} \\
\hline BRS Tamani & $7.2 \mathrm{~b}$ & $8.9 \mathrm{~b}$ & $24.3 \mathrm{a}$ \\
\hline \multirow[t]{2}{*}{ BRS Piatã } & $12.3 b$ & $4.6 \mathrm{c}$ & $43.0 \mathrm{a}$ \\
\hline & & - -qMIC $(\%$ & 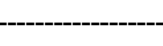 \\
\hline BRS Tamani & $2.6^{\mathrm{ns}}$ & 1.9 & 1.8 \\
\hline BRS Piatã & $2.8 \mathrm{a}$ & $3.0 \mathrm{a}$ & $1.1 \mathrm{~b}$ \\
\hline
\end{tabular}

(1)Means followed by equal letters in the rows, do not differ by the Tukey's test, at $5 \%$ probability. ${ }^{\text {ns }}$ Nonsignificant. 
pea, provided reductions of $220 \%$ for BR and $834 \%$ for $\mathrm{qCO}_{2}$, in comparison to the single cultivation.

Low- $\mathrm{qCO}_{2}$ values are related to environments that are more stable or closer to their equilibrium state, as they indicate energy savings. However, the opposite indicates ecosystems that were subjected to some conditions of stress or disturbance (Silva et al., 2010). Therefore, the use of legumes intercropped with grasses in ICLS meant an improvement in the biological attributes of the soil, which may contribute in the long run to achieve the equilibrium in the production system, since it showed low- $\mathrm{qCO}_{2}$ values, but maintained qMIC indices high, evidencing that the microbial biomass is not under stress and is able to use organic $\mathrm{C}$ efficiently, that is, incorporating it into its own metabolism.

In addition to microbiological indicators, enzymes are also highly used to evaluate the soil quality due to their sensitivity in providing information on the system management (Lisboa et al., 2012). In the present study, the $\beta$-glucosidase enzyme was not influenced by the intercrop; the effect was significant only for grasses, especially 'BRS Tamani', which showed this enzyme activity $57.2 \%$ higher than that in 'BRS Piatã' (Table 4). In addition, acid phosphatase was not influenced by intercrops, or by grasses, in the short term, and it was characterized as a slightly sensitive indicator in comparison to the type of management under the conditions of this study. These results may also be related to fertilization, since it may have deprived the activity of this enzyme. Ye et al. (2017) reported a reduction of the acid phosphatase activity, and associated this result with the excess $P$ available in the soil. This fact is corroborated by the present study, in which the soil had much higher levels of $\mathrm{P}(28.2 \mathrm{mg}$ $\mathrm{dm}^{-3}$ ) than those required for soybean cultivation. In this context, low-P levels in the soil help to increase the acid phosphatase activity, considering that contents that are higher than $12 \mathrm{mg} \mathrm{dm}^{-3}$ are considered high for the soil (Milanesi, 2015).

The activity of the urease enzyme was increased by the intercrop with pigeon pea by about $109 \%$ in comparison to the single culture (Table 4). The intercrop with cowpea did not differ from the single crop, despite promoting a $31.6 \%$ increase. These results are probably due to the high deposition of plant residues with a high- $\mathrm{C} / \mathrm{N}$ ratio, which stimulated the increase of the microorganism diversity. Lanna et al. (2010) observed low values for urease activity in areas cultivated with legumes, attributing the results to the low- $\mathrm{C} / \mathrm{N}$ ratio of these plant species that provides a rapid decomposition. However, some authors have observed that some leguminous species, such as pigeon pea, when cultivated in the Cerrado area, have a higher- $\mathrm{C} / \mathrm{N}$ ratio due to a woody stem, less leaves, and a biannual aspect (Cesar et al., 2011).

For the enzymes arylsulfatase and FDA, there was an interaction between grasses and legumes, in which 'BRS Piatã' intercropped with pigeon pea increased arylsulfatase activity by $64.9 \%$ in comparison to the single crop (Table 5). This result corroborates that by Lisboa et al. (2012), who emphasized that a high diversity of cultures positively influences the volume of soil organic matter and deposited plant material, besides improving the rhizosphere in the soil, contributing to the increase of this enzyme activity.

Table 4. Activity of the enzymes $\beta$-glucosidase, acid phosphatase, and urease, in an integrated crop-livestock system managed in no-tillage with intercropping at the pasture phase $\mathrm{e}^{(1)}$.

\begin{tabular}{|c|c|c|c|}
\hline \multirow[t]{2}{*}{ Grass/intercrop } & $\beta$-glucosidase & Acid phosphatase & \multirow{2}{*}{$\begin{array}{c}\text { Urease } \\
\left(\mathrm{g} \mathrm{N}-\mathrm{NH}_{4} \mathrm{~g}^{-1} \text { soil each } 2 \text { hours }\right)\end{array}$} \\
\hline & \multicolumn{2}{|c|}{-----------( $\mu \mathrm{g}$ p-nitrofenol g ${ }^{-1}$ soil per hour)----------- } & \\
\hline & & Grasses & \\
\hline BRS Tamani & $329.8 \mathrm{~A}$ & $648^{\mathrm{ns}}$ & $12^{\mathrm{ns}}$ \\
\hline \multirow[t]{2}{*}{ BRS Piatã } & $209.8 \mathrm{~B}$ & 576.6 & 17.6 \\
\hline & & Intercrops & \\
\hline Cowpea & $270.5^{\mathrm{ns}}$ & $615.2^{\mathrm{ns}}$ & $13.3 \mathrm{ab}$ \\
\hline Pigeon pea & 266 & 683.1 & $21.1 \mathrm{a}$ \\
\hline Single crop & 272.8 & 538.4 & $10.1 b$ \\
\hline
\end{tabular}


Only the intercrop with 'BRS Piatã' showed significant differences, by obtaining the greatest activities in the intercrop with cowpea (Table 5), which increased the activity of arylsulfatase in comparison to the intercrop with pigeon pea and single crop, respectively, by 9

Table 5. Activity of arylsulfatase and fluorescein diacetate hydrolysis (FDA), in an integrated crop-livestock system managed in no-tillage system with intercropping at the pasture phase $^{(1)}$.

\begin{tabular}{lccc}
\hline Grass & \multicolumn{3}{c}{ Intercrop } \\
\cline { 2 - 4 } & Cowpea & Pigeon pea & Single crop \\
\hline \multirow{3}{*}{ BRS Tamani } & Arylsulfatase $\left(\mathrm{g}\right.$ p-nitrofenol $\mathrm{g}^{-1}$ & soil per hour $)$ \\
BRS Piatã & $54.2^{\mathrm{ns}}$ & 65.6 & 52.3 \\
& $56.2 \mathrm{~b}$ & $109.0 \mathrm{a}$ & $66.1 \mathrm{~b}$ \\
BRS Tamani & FDA (mg fluorescein $\mathrm{g}^{-1}$ soil per hour) \\
BRS Piatã & $10.1^{\mathrm{ns}}$ & 11.1 & 10.5 \\
\hline
\end{tabular}

(1) Means followed by equal letters in the rows, do not differ by the Tukey's test, at $5 \%$ probability. ${ }^{\text {ns }}$ Nonsignificant. and $66 \%$. The lowest activity of this enzyme in the intercrop with pigeon pea may have occurred because of the woodier residue being of this grass than the other treatments. Lisboa et al. (2012) affirmed that the addition of more labile organic materials helps the activity of this enzyme, since it participates in the modifications of the soil organic matter.

The principal component analysis (PCA) explained $75.7 \%$ of the total data variance $(38.80 \%$ in $\mathrm{PC} 1$, and $36.90 \%$ in PC2) (Figure 3). On the left, the PC1 axis was influenced especially by the set of variables associated with productivity, in which N-MB, C-MB, and E-COT are represented by positive eigenvectors, while qMIC, urease, and arylsulfatase are represented by negative eigenvectors. Still in PC1, the negative eigenvectors, on the right, loaded the attributes $\mathrm{BR}$ and $\mathrm{qCO}_{2}$, which are indicators of stress conditions. In turn, PC2 also characterized the attributes associated with the elevation of soybean yield that is represented by positive eigenvectors related to $\beta$-glucosidase, phosphatase, and FDA attributes.

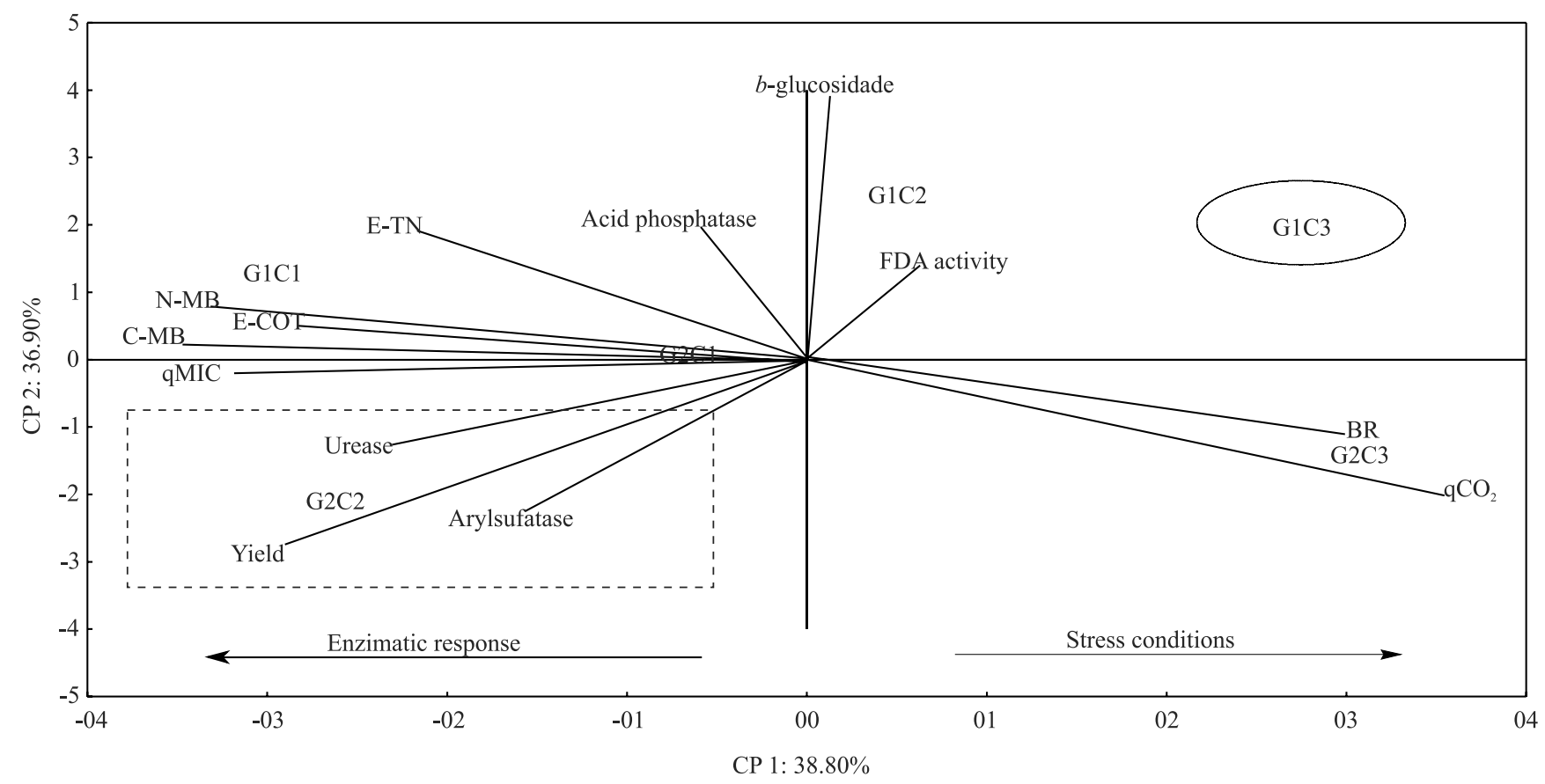

Figure 3. Distribution of the indicators of the soil biological quality, intercrops, and soybean yield, in an integrated croplivestock system managed in no-tillage with intercropping at the pasture phase. G1C1, 'BRS Tamani' grass intercropped with cowpea; G1C2, 'BRS Tamani' grass intercropped with pigeon pea; G1C3, 'BRS Tamani' in single cultivation; G2C1, 'BRS Piatã' grass intercropped with cowpea; G2C2, 'BRS Piatã' intercropped with pigeon pea; G2C3, 'BRS Piatã', in single cultivation. 
According to the PCA, the increase of soybean yield was conditioned by 'BRS Piatã' and 'BRS Tamani' grasses intercropped with cowpea and pigeon pea (G1C1, G1C2, G2C1, and $\mathrm{G} 2 \mathrm{C} 2$ ) at the pasture stage. However, the behavior of the eigenvectors from the $\mathrm{G} 1 \mathrm{C} 1$ and $\mathrm{G} 2 \mathrm{C} 2$ intercrops, positioned closer the $\mathrm{CP} 1$ extremes, indicates that when soybean is grown after intercropping between grasses and legumes, a maximum productivity is achieved. These results confirm what has been discussed, that is, soybean productivity is based on several attributes related to soil microbiology and not only to soil chemical fertility. When analyzing all the indicators presented in the research, it can be observed that the increase of diversity due to the use of legumes in ICLS-NTS, besides bringing benefits to the environment because of a more sustainable production, also improves the soil quality, resulting in the increase of soybean crop productivity.

In the same component, it can be observed that the grasses 'BRS Piatã' and 'BRS Tamani', cultivated as single crops (G2C3 and G1C3), located in the opposite direction to productivity, which indicates that there is no relation with the increase of soybean yield, and that is better characterized by stress indicators. This suggests that grasses, when cultivated alone, show a greater energy demand to maintain the microbial activity, which increases the stress and, as a consequence, makes them unable to use the soil organic $\mathrm{C}$ efficiently (Silva et al., 2010).

The PCA obtained by the univariate analysis showed that the increase of soybean productivity occurred in the following sequence: $\mathrm{G} 2 \mathrm{Cl}>\mathrm{G} 2 \mathrm{C} 2>\mathrm{G} 1 \mathrm{Cl}>\mathrm{G} 1 \mathrm{C} 2$, confirming the successful implementation of the ICLSNTS associated to the intercropping with legumes at the pasture phase.

It is worth highlighting that the ICLS-NTS, even in its "conventional mode" without intercropping, obtained high productivity, with a two-year average yield of 3,215 $\mathrm{kg} \mathrm{ha}^{-1}$ (Figure 2); this value is similar to the average of Mato Grosso state, Brazil (Acompanhamento..., 2017), proving once again that the implementation of these production systems, even when in single crops at the pasture phase, regains the balance of the environment, which provides profitability to producers with the potentiating of productivity. However, this research aimed at seeking improvements for systems that were already installed; thus, this work verified that the increase of species diversity, through the inclusion of legumes at the pasture phase of the system, provides significant results for soil quality that reflects in the soybean yield (Figure 2).

\section{Conclusions}

1. The intercrop with legumes at the pasture phase of integrated crop-livestock system and no-tillage system increases the soil organic matter, also promoting increases of $\mathrm{C}$ and $\mathrm{N}$ stocks.

2. Intercrops provide the increase of $\mathrm{C}$ and $\mathrm{N}$ of the microbial biomass, whereas single cultures cause stress in the microbiota by the increase of the basal respiration and metabolic quocient $\left(\mathrm{qCO}_{2}\right)$.

3 . The activity of the urease enzyme is sensitive to changes in the management in the short term; acid phosphatase and $\beta$-glucosidase are slightly sensitive indicators to the type of management under the conditions of the present study.

4. The improvement of the attributes that indicate soil quality, provided by the insertion of legumes in intercropping, reflects in the increase of soybean productivity.

\section{Acknowledgments}

To Conselho Nacional de Pesquisa e Desenvolvimento (CNPq), for granting productivity scholarships to the fifth, eighth, and tenth authors, and for financial support to carry out the project; to Rede ILPF, for financial support; and to Mr. Caetano Polato, for the permission to use the experimental area.

\section{References}

ACOMPANHAMENTO DA SAFRA BRASILEIRA [DE] GRÃOS: safra 2016/17: décimo levantamento, v.4, n.10, jul. 2017.

ALVES, T. dos S.; CAMPOS, L.L.; ELIAS NETO, N.; MATSUOKA, M.; LOUREIRO, M.F. Biomassa e atividade microbiana de solo sob vegetação nativa e diferentes sistemas de manejos. Acta Scientiarum. Agronomy, v.33, p.341-347, 2011. DOI: 10.4025/actasciagron.v33i2.4841.

ANDERSON, T.-H.; DOMSCH, K.H. The metabolic quocient for $\mathrm{CO} 2(\mathrm{qCO} 2)$ as a specific activity parameter to assess the effects of environmental conditions, such as $\mathrm{pH}$, on the microbial biomass of forest soils. Soil Biology and Biochemistry, v.25, p.393-395, 1993. DOI: 10.1016/0038-0717(93)90140-7.

BROOKES, P.C.; LANDMAN, A.; PRUDEN, G.; JENKINSON, D.S. Chloroform fumigation and the release of soil nitrogen: a rapid direct extration method to measure microbial biomass 
nitrogen in soil. Soil Biology and Biochemistry, v.17, p.837-842, 1985. DOI: 10.1016/0038-0717(85)90144-0.

CARVALHO, J. dos S.; KUNDE, R.J.; STÖCKER, C.M.; LIMA, A.C.R. de; SILVA, J.L.S. da. Evolução de atributos físicos, químicos e biológicos em solo hidromórfico sob sistemas de integração lavoura-pecuária no bioma Pampa. Pesquisa Agropecuária Brasileira, v.51, p.1131-1139, 2016. DOI: 10.1590/ s0100-204x2016000900012.

CESAR, M.N.Z.; GUERRA, J.G.M.; RIBEIRO, R. de L.D.; URQUIAGA, S.S.C.; PADOVAN, M.P. Performance de adubos verdes cultivados em duas épocas do ano no Cerrado do Mato Grosso do Sul. Revista Brasileira de Agroecologia, v.6, p.159169, 2011.

CHÁVEZ, L.F.; ESCOBAR, L.F.; ANGHINONI, I.; DE FACCIO CARVALHO, P.C.; MEURER, E.J. Diversidade metabólica e atividade microbiana no solo em sistema de integração lavoura pecuária sob intensidades de pastejo. Pesquisa Agropecuária Brasileira, v.46, p.1254-1261, 2011. DOI: 10.1590/S0100204X2011001000020.

CICEK, H.; MARTENS, J.R.T.; BAMFORD, K.C.; ENTZ, M.H. Forage potential of six leguminous green manures and effect of grazing on following grain crops. Renewable Agriculture and Food Systems, v.30, p.503-514, 2014. DOI: 10.1017/ S1742170514000349.

ClAESSEN, M.E.C. (Org.). Manual de métodos de análises de solo. 2.ed. rev. e atual. Rio de Janeiro: Embrapa-CNPS, 1997. 212p. (Embrapa-CNPS. Documentos, 1).

COSTA, N.R.; ANDREOTTI, M.; LOPES, K.S.M.; YOKOBATAKE, K. L.; FERREIRA, J.P.; PARIZ, C.M.; LONGHINI, V.Z. Atributos do solo e acúmulo de carbono na integração lavoura-pecuária em sistema plantio direto. Revista Brasileira de Ciência do Solo, v.39, p.852-863, 2015. DOI: 10.1590/01000683rbcs20140269.

DENINSON, R.F.; HARTER, B.L. Nitrate effects on nodule oxygen permeability and leghemoglobin: nodule oximetry and computer modeling. Plant Physiology, v.107, p.1355-1364, 1995. DOI: $10.1104 / p p .107 .4 .1355$.

DICK, R.P.; BREAKWELL, D.P.; TURCO, R.F. Soil enzyme activities and biodiversity measurements as integrative microbiological indicators. In: DORAN, J.W.; JONES, A.J. (Ed.). Methods for assessing soil quality. Madison: Soil Science Society Of America, 1996. p.247-271. SSSA Special Publication n. 49. DOI: $10.2136 /$ sssaspecpub49.c15.

EIVAZI, F.; TABATABAI, M.A. Glucosidases and galactosidases in soils. Soil Biology and Biochemistry, v.20, p.601-606, 1988. DOI: 10.1016/0038-0717(88)90141-1.

ELLERT, B.H.; BETTANY, J.R. Calculation of organic matter and nutrients stored in soils under contrasting management regimes. Canadian Journal of Soil Science, v.75, p.529-538, 1995. DOI: 10.4141/cjss95-075.

FERREIRA, D.F. Sisvar: a computer statistical analysis system. Ciência e Agrotecnologia, v.35, p.1039-1042, 2011. DOI: 10.1590/ S1413-70542011000600001.
FRANZLUEBBERS, A.J.; STUEDEMANN, J.A. Soil-profile organic carbon and total nitrogen during 12 years of pasture management in the Southern Piedmont USA. Agriculture, Ecosystems and Environment, v.129, p.28-36, 2009. DOI: 10.1016/j.agee.2008.06.013.

FRASIER, I.; NOELLEMEYER, E.; FIGUEROLA, E.;ERIJMAN, L.; PERMINGEAT, H.; QUIROGA, A. High quality residues from cover crops favor changes in microbial community and enhance $\mathrm{C}$ and $\mathrm{N}$ sequestration. Global Ecology and Conservation, v.6, p.242-256, 2016. DOI: 10.1016/j.gecco.2016.03.009.

GAZOLLA, P.R.; GUARESCHI, R.F.; PERIN, A.; PEREIRA, M.G.; ROSSI, C.Q. Frações da matéria orgânica do solo sob pastagem, sistema plantio direto e integração lavoura-pecuária. Semina: Ciências Agrárias, v.36, p.693-704, 2015. DOI: 10.5433/1679-0359.2015v36n2p693.

JENKINSON, D.S.; POWLSON, D.S. The effects of biocidal treatments on metabolism in soil - V: a method for measuring soil biomass. Soil Biology and Biochemistry, v.8, p.209-213, 1976. DOI: 10.1016/0038-0717(76)90005-5.

KAISER, H.F. The varimax criterion for analytic rotation in factor analysis. Psychometrika, v.23, p.187-200, 1958. DOI: 10.1007/BF02289233.

LANNA, A.C.; SILVEIRA, P.M. da; SILVA, M.B. da; FERRARESI, T.M.; KLIEMANN, H.J. Atividade de urease no solo com feijoeiro influenciada pela cobertura vegetal e sistemas de plantio. Revista Brasileira de Ciência do Solo, v.34, p.19331939, 2010. DOI: 10.1590/S0100-06832010000600018.

LISBOA, B.B.; VARGAS, L.K.; SILVEIRA, A.O. da; MARTINS, A.F.; SELBACH, P.A. Indicadores microbianos de qualidade do solo em diferentes sistemas de manejo. Revista Brasileira de Ciência do Solo, v.36, p.45-55, 2012. DOI: 10.1590/S010006832012000100004.

MILANESI, J.H. Adubação da cultura da soja baseada nos teores mínimos de fósforo e potássio no solo. 2015. 73p. Dissertação (Mestrado) - Universidade Federal de Santa Maria, Santa Maria.

ROESCH-MCNALLY, G.E.; ARBUCKLE, J.G.; TYNDALL, J.C. Barriers to implementing climate resilient agricultural strategies: The case of crop diversification in the U.S. Corn Belt. Global Environmental Change, v.48, p.206-215, 2018. DOI: 10.1016/j. gloenvcha.2017.12.002.

RYSCHAWY, J.; MARTIN, G.; MORAINE, M.; DURU, M.; THEROND, O. Designing crop-livestock integration at different levels: toward new agroecological models? Nutrient Cycling in Agroecosystems, v.108, p.5-20, 2017. DOI: 10.1007/s10705-0169815-9.

SANTOS, H.G. dos; JACOMINE, P.K.T.; ANJOS, L.H.C. dos; OLIVEIRA, V.A. de; LUMBRERAS, J.F.; COELHO, M.R.; ALMEIDA, J.A. de; CUNHA, T.J.F.; OLIVEIRA, J.B. de. Sistema brasileiro de classificação de solos. 3.ed. rev. e ampl. Brasília: Embrapa, 2013a. 353p.

SILVA, R.R. da; SILVA, M.L.N.; CARDOSO, E.L.; MOREIRA, F.M. de S.; CURI, N.; ALOVISI, A.M.T. Biomassa e atividade microbiana em solo sob diferentes sistemas de manejo na região fisiográfica Campos das Vertentes - MG. Revista Brasileira de 
Ciência do Solo, v.34, p.1584-1592, 2010. DOI: 10.1590/S010006832010000500011.

SPARLING, G.P.; WEST, A.W. A direct extraction method to estimate soil microbial C: Calibration in situ using microbial respiration and $14 \mathrm{C}$ labelled cells. Soil Biology and Biochemistry, v.20, p.337-343, 1988. DOI: 10.1016/0038-0717(88)90014-4.

TABATABAI, M.A. Soil enzymes. In: WEAVER, R.W.; ANGLE, S.; BOTTOMLEY, P.; BEZDICEK, D.; SMITH, S.; TABATABAI, A.; WOLLUM, A. (Ed.). Methods of soil analysis: microbiological and biochemical properties. Madison: Soil Science Society of America, 1994. Part 2, p.775-833.

TABATABAI, M.A.; BREMNER, J.M. Assay of urease activity in soils. Soil Biology and Biochemistry, v.4, p.479-487, 1972. DOI: 10.1016/0038-0717(72)90064-8.

TANAKA, R.T.; MASCARENHAS, H.A.A.; DIAS, O.S.; CAMPIDELLI, C.; BULISANI, E.A. Cultivo da soja após incorporação de adubo verde e orgânico. Pesquisa Agropecuária Brasileira, v.27, p.1477-1483, 1992.

TATE, K.R.; ROSS, D.J.; FELTHAM, C.W. A direct extraction method to estimate soil microbial $\mathrm{C}$ : effects of experimental variables and some different calibration procedures. Soil Biology and Biochemistry, v.20, p.329-335, 1988. DOI: 10.1016/00380717(88)90013-2.

VANCE, E.D.; BROOKES, P.C.; JENKINSON, D.S. An extraction method for measuring soil microbial biomass C. Soil Biology and Biochemistry, v.19, p.703-707, 1987. DOI: 10.1016/00380717(87)90052-6.

YE, D.; LI, T.; ZHANG, X.; ZHENG, Z.; DAI, W. Rhizosphere $\mathrm{P}$ composition, phosphatase and phytase activities of Polygonum hydropiper grown in excess $\mathrm{P}$ soils. Biology and Fertility of Soils, v.53, p.823-836, 2017. DOI: 10.1007/ s00374-017-1218-9.

Received on August 31, 2017 and accepted on May 6, 2018 